\title{
Analysis of the Wheat Straw/Flax Fiber Reinforced Polymer Hybrid Composites

\author{
EI Messiry $M^{*}$ and EI Deeb R
}

Textile Engineering Department, Faculty of Engineering, Alexandria University, Alexandria, Egypt

\begin{abstract}
In the last decades, the agro wastes in manufacturing different types of composites found the increasing utilization. The world statistics of the Wheat and rice straw indicates that about 710 million metric tons of Wheat straw and 670 million tons of rice straw are produced each year as the agricultural waste, beside the other cereal and forest waste. Therefore, it causes a huge environmental impact and this problem is growing each year. The production of plastic composites from agro waste materials is receiving the substantial consideration currently. In this work, we suggest to use the Wheat straw in its whole shape instead of shredded one for forming the green composite. The hybrid composite was formed of Wheat straw, flax fiber, and jute fabric. This study targets at the mechanical properties of Wheat straw. The results indicate the possibility of manufacturing of the thin plates and shafts from such hybrid combinations after the increasing the crushing force of Wheat straw.
\end{abstract}

Keywords: Natural fibers; Green composite; Crushing force; Agro waste; Wheat straw

\section{Introduction}

Composite materials have been known to mankind for thousands of years, and occur naturally in many living things. The earliest composite materials were straw reinforced bricks [1]. Currently, natural fibers, mainly flax and hemp, are available as commercial products as short fibers for injection molding compounds or as non-woven mats based on short fibers organized in a random array. Enhancing the adhesion between the natural fibers and matrices results in improving composite strength and toughness [2-6].

Green composite combines plant fibers with natural resins to create natural composite materials. Biomaterial composites are made from hemp, kenaf, sisal, soybean, etc. Natural fibers are emerging as low cost, lightweight and apparently environmentally superior alternative to synthetic fibers [7]. The agriculture waste is one of the problems of the modern intensive agriculture which needs innovative methods for its useful industrial applications. The development of composites from renewable raw materials has increased considerably during the last years as they are environmentally friendly materials. Natural fibers are renewable, easily recycled, carbon dioxide neutral, and are available in large quantities. In addition, they have high specific properties and cause less health problems during handling when compared to glass fibers. Hence, apart from the low cost of agro-waste, there is interest nowadays to environment and biodegradability properties of materials to actualize the scale up production of agro waste plastic composites by the formation and synthesis of these filler fibers. Various methods are required for mixing filler husks at different filler blend ratio $[1,8$ 10]. Several researchers $[7,8]$ exploit the facts of value-added and ultralight composite products from Wheat straw for the implementation in the automotive and transportation industries. With natural fiber composites, car weight reduction up to $35 \%$ is possible. This can be translated into lower fuel consumption and the lower environmental impact. Natural fiber based composites also offer good mechanical performance, good formability, high sound absorption, and cost savings due to low material costs. Moreover, their "Green look" as well as ecological and logistical benefits of the natural fiber based technologies looks more attractive. In 2000, more than 23,000 tons of natural fibers have been used in the automotive sector alone furthermore, natural fibers in the automotive industry should experience a sustainable growth as EU regulations regarding recycling and "End of life vehicle" directives set car recycling targets to $95 \%$ by 2015 [7].

The world statistics of the Wheat and rice straw indicates that there are about 710 million metric tons of Wheat straw and 670 million ton of rice straw each year. The introduction an innovative environmentally friendly process for turning agricultural residues (agro-waste) into quality products suitable for use for the industrials is always urged $[1,11]$. The use of straw has been gaining much research attention as a potential alternative lignocellulosic raw material replacing wood for making composites, particularly for particleboards [12-16]. The agro waste may be used individually or in combination with each other to achieve desired structure of agro waste plastic composites. An understanding of the available composites fabrications processes and how they apply to different composites is a necessary requirement for proper selection of composite design for engineering. The characteristic of composite depends on the nature of the reinforcement, the ratio of resin, such as Polyethylene Terephthalate (PETE), High Density Polyethylene (HDPE), PolyvinylChloride (PVC), Low Density Polyethylene (LDPE) and Polypropylene (PP), Polystyrene (PS), to reinforcement and the mode of fabrication [17].

Mechanical properties of the composites with Wheat straw as filler showed better mechanical properties compared to cornstalk and corncob, which is resulted from the good compatibility between the more non-polar surface of Wheat straw and HDPE [18].

The techniques that are used to manufacture the bio-composites are based on existing plastic processing methods. These methods can be used with thermoplastics or thermosetting polymers [1,19].

*Corresponding author: Magdi El Messiry, Textile Engineering Department, Faculty of Engineering, Alexandria University, Alexandria, Egypt, Tel: +20 3 5921675; E-mail: mmessiry@yahoo.com

Received September 29, 2016; Accepted November 24, 2016; Published November 28, 2016

Citation: El Messiry M, El Deeb R (2016) Analysis of the Wheat Straw/Flax Fiber Reinforced Polymer Hybrid Composites. J Appl Mech Eng 5: 240. doi: 10.4172/2168-9873.1000240

Copyright: (c) 2016 El Messiry M, et al. This is an open-access article distributed under the terms of the Creative Commons Attribution License, which permits unrestricted use, distribution, and reproduction in any medium, provided the original author and source are credited. 
Citation: El Messiry M, El Deeb R (2016) Analysis of the Wheat Straw/Flax Fiber Reinforced Polymer Hybrid Composites. J Appl Mech Eng 5: 240. doi: $10.4172 / 2168-9873.1000240$

For thermoplastic composite, the manufacturing methods include extrusion, injection moulding and compression moulding. One of the main limitations of compounding and injection moulding is that only relatively short natural fibers can be used [20]. If longer fibers to be involved, alternative methods, such as co-mingling in the form of a non-woven fleece, should be implemented.

The Wheat straw, usually as short lengths, febrile, or after grinding as a micro size particles is used. Literatures not readily accessible to use of whole stem of the Wheat straw to form the composites. This study targets at the mechanical properties of whole stem of Wheat straw as well as the manufacturing methods for Wheat straw/flax fiber to produce low density hybrid composite.

\section{Materials and Methods}

\section{Materials}

Wheat straw: Wheat straw obtained from Egyptian local farmers was cut into $19-20 \mathrm{~cm}$ lengths without nods and used for preparing Wheat straw composite.

Flax fibers: Egyptian Long staple combed flax fibers were used of fiber length $110 \mathrm{~mm}$ and fiber diameter $20 \mu \mathrm{m}$. The fiber breaking strength is $547.1 \mathrm{Mpa}$, breaking strain is 0.01458 , and Modulus of elasticity is $37.52 \mathrm{GP}$.

Properties of flax fabric: Flax fabric is used with the following specifications: weight $290 \mathrm{~g} / \mathrm{m} 2$, thickness $0.43 \mathrm{~mm}$, tensile strength $0.03625 \mathrm{GPA}$, breaking elongation $9.3 \%$, fabric design plain weave $1 / 1$, and cover factor 0.37 with equal ends/ $\mathrm{cm}$ and picks/cm 4.5 . Warp count and the weft count are 246 tex and 311 tex, respectively. Fabric tensile strength was done on a fabric tensile tester machine with load capacity $5000 \mathrm{~N}$.

\section{Fiber diameter measurement}

Flax fiber diameter is measured manually by using an optical microscope. The results reported are averages of 50 samples. The measuring of fiber diameter was done on LEICA DME microscope as shown in Figure 1.

Tensile strength testing: Tensile testing was done on a TITAN2 Universal strength tester machine (Model 710) with load capacity $3000 \mathrm{~N}$. TITAN2 Universal strength tester software was used for data acquisition. The testing for the flax fiber samples was done at gauge length $3 \mathrm{~cm}$, the cross-head displacement rate at $10 \mathrm{~mm} / \mathrm{min}$. The results reported are averages of five samples. The specimen ends were clamped into the hydraulic jaws of the testing machine as shown in Figure 2 .

Wheat straw crushing force: For the determination of the crushing force, special attachment was designed for measuring the crushing force required to crack the Wheat straw; the straw is pressed against a flat surface by a force at the middle portion till a crack is started under the applied load. Figure 3 shows the principle of the attachment.

\section{Results and Discussion}

There are three important physical structural features of Wheat straw which make it an excellent fiber and filler source for thermoset composite materials, i.e., intricate percolating pore structure of vascular bundles and central void, presence of micro fibrils in the structure, and existence of polymer lignin near the surface of the straw. However, the lack of cross-linking between polymers and Wheat straw fibers has been a major stumbling block for straw fiber utilization in various composite materials [21].

Figure 4 shows SEM image of a cross sectioned raw Wheat straw from the internode region of the stem with noticeable hollow pith and the scattered placement of the vascular bundles close to the epidermis [5]. The use of the straw in this case will give low strength composites.

\section{Composites preparation}

With the anticipation to improve the mechanical properties of the Wheat straw, we suggested infusing risen, protein colloid glues, inside the Wheat straw Lumina. Collagen consists of long protein molecules composed of naturally occurring amino acids that are linked in a specific sequence by covalent peptide bonds. Due to the spatial conformation of some amino acid groups (notably proline and hydroxyproline) and the many ionisable and polar functional groups in the protein chain, the

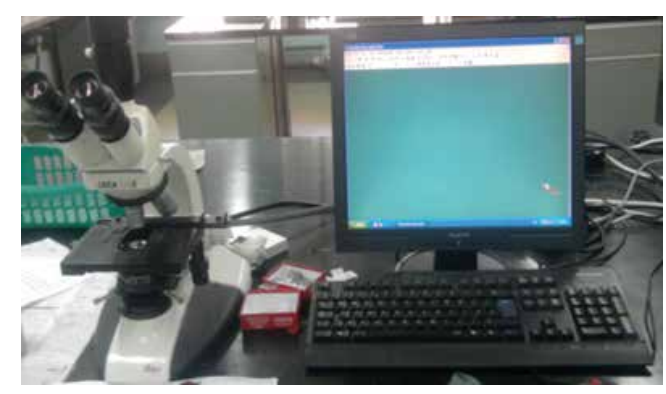

Figure 1: LEICA DME optical microscope.

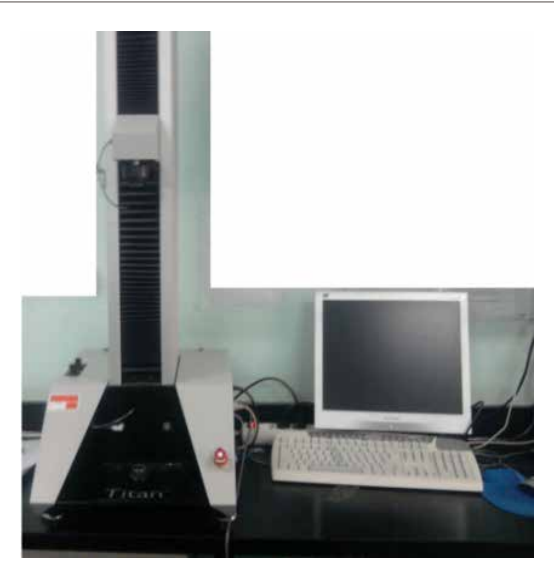

Figure 2: TITAN2 Universal strength tester machine.

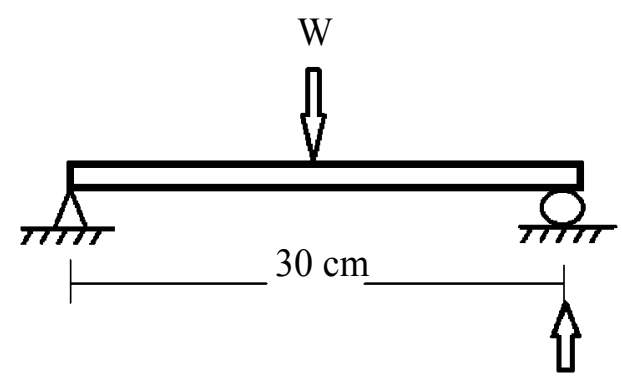

F

Figure 3: Principle of crushing force attachment. 
Citation: El Messiry M, El Deeb R (2016) Analysis of the Wheat Straw/Flax Fiber Reinforced Polymer Hybrid Composites. J Appl Mech Eng 5: 240. doi: $10.4172 / 2168-9873.1000240$

Page 3 of 5

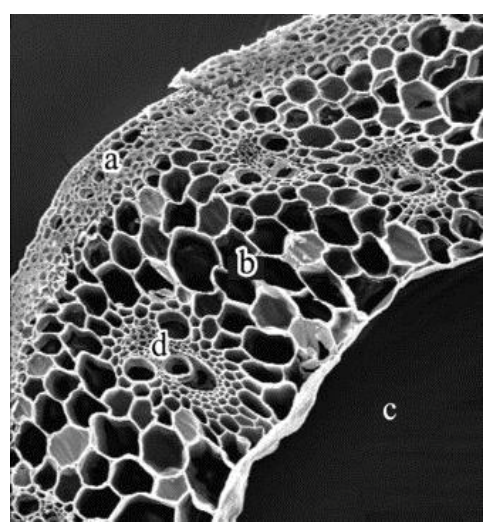

Figure 4: SEM image of a cross sectioned raw Wheat straw from the internode region of the stem [5]. (a) Epidermis, (b) Parenchyma, (c) Lumen, and (d) Vascular bundles.

individual chains form triple-stranded helical coils that are generally believed to be internally stabilized by hydrogen-bonding [22-24].

Animal glues are considered as eco-adhesives. They are nontoxic, environmentally friendly, and biodegradable. Animal glue formulations begin to break down in the natural environment in a matter of weeks when disposed of. It is composed of technical gelatin, usually extracted from collagen found in hides and/or bones of cattle. Other ingredients include Epsom salts, water, natural corn sugars, and glycerin. Chemical composition of hide glue is a protein derived from the simple hydrolysis of collagen which is a principal protein constituent of animal hides. Collagen, hide glue and gelatin are very closely related as to protein and chemical composition [25-27]. Through the infusion of the risen inside the Lumina, the inner wall of the straw will absorb the glue which is water soluble and penetrating in the open areas in the stem cross section. According to the mechanical interlocking theory, adhesive strength is provided by interlocks which are formed when the adhesive penetrates into the pores and cavities of the substrate, causing an increase of wall strength. Formation of the composite using treated Wheat straw will follow this preparation.

Cross-section of Wheat straw treated and untreated with natural glue illustrating glue penetration in parenchyma as black spot areas is shown in Figures 5a and 5b.

\section{Wheat straw preparation}

In this work, special technique was used to strengthen Wheat straw through the infusion of the gelatin glue through the internal channel of the straw, using a special attachment as shown in Figure 6.

After the infusion of the gelatin glue inside the Wheat straw, it was dried on the air at room temperature for 24 hours or dried using hot air oven at temperature of $105^{\circ} \mathrm{C}$ for one hour. The result was a composite with fiber volume fraction of 0.57 . The tensile strength of the treated Wheat straw was measured using Titan2 Universal strength tester machine (Model 710) with load capacity $3000 \mathrm{~N}$ and with crosshead speed of $10 \mathrm{~mm} / \mathrm{min}$. Test specimens were of average diameter 6.0 $\mathrm{mm}$ wide and $200 \mathrm{~mm}$ long. For each sample, 10 specimens were tested and the average tensile modulus and strengths were estimated. All test samples were preconditioned at $65 \%$ relative humidity, $23^{\circ} \mathrm{C}$ for $48 \mathrm{~h}$.

\section{Tensile properties of treated wheat straw}

The tensile properties of Wheat straw/glue are given in Table 1. The mechanical properties of the straw composite represent the increase of straw strength by about $166 \%$, breaking strain by $125 \%$, and the Young's Modulus by $130 \%$.

The increase in the tensile strength is a direct effect of the absorption of the Wheat straw wall of the glue in the areas b and $d$ in Figure 2. Also the Young's modulus of was increased.

\section{Straw crushing force}

The stems of the Wheat straw are solid at the nodes but internodes are hollow. The dimension of the Wheat straw depends on its variety. The crushing force, which is the force required to collapse the cross section of the Wheat straw, depends on its hollowness, the term hollowness as referred to here is the ratio of inner diameter of the wheat straw to the outer diameter expressed in percentage [22] (Figure 7).

The value of the hollowness:

$$
\mathrm{H}=\left(\mathrm{D}_{\text {in }} / \mathrm{D}_{\text {out }}\right) * 100
$$

The hollowness of Wheat straw is laying in the range of $90 \%$ to 95\% [21].

The deformation of the Wheat straw cross section under the crushing force is illustrated in Figure 8. The study of hollowness effect

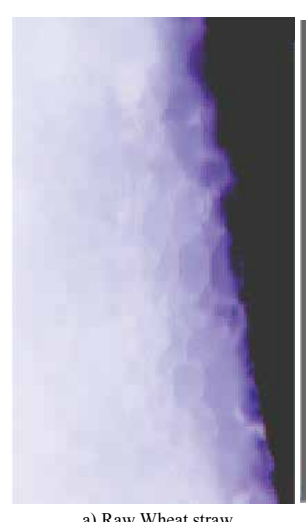

a) Raw Wheat straw

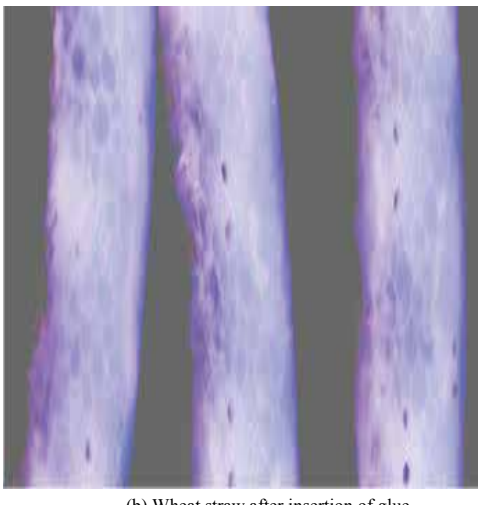

(b) Wheat straw after insertion of glue
Figure 5: Wheat straw wall cross-section after insertion of glue.

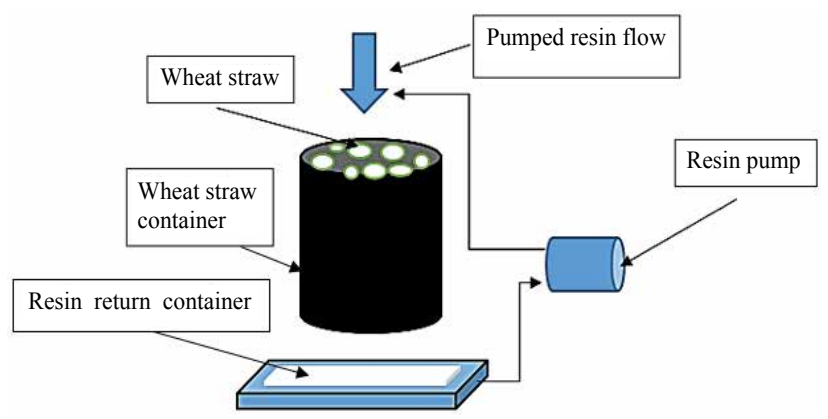

Figure 6: Sketch of wheat straw preparation attachment.

\begin{tabular}{|l|c|c|c|c|}
\hline \multicolumn{1}{|c|}{ Material } & $\begin{array}{c}\text { Strain } \\
\text { (\%) }\end{array}$ & $\begin{array}{c}\text { Strength } \\
\text { (MPa) }\end{array}$ & $\begin{array}{c}\text { Young's } \\
\text { Modulus (MPa) }\end{array}$ & $\begin{array}{c}\text { Volume } \\
\text { fraction Vf (\%) }\end{array}$ \\
\hline Raw wheat straw & 0.0151 & 14.7 & 973.899 & 100 \\
\hline $\begin{array}{c}\text { Wheat straw/glue } \\
\text { composite }\end{array}$ & 0.02 & 24.35 & 1217.685 & 55.6 \\
\hline
\end{tabular}

Table 1: Mechanical properties of the wheat straw composite. 


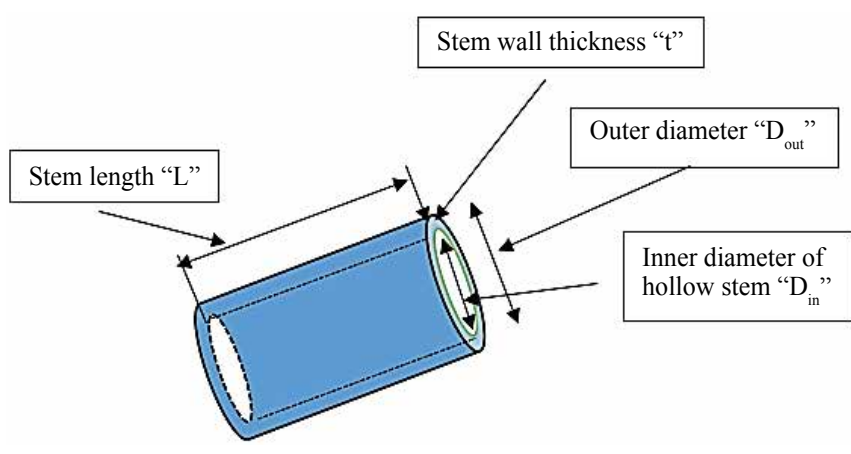

Figure 7: Dimensions of a stem assuming cylindrical shape.

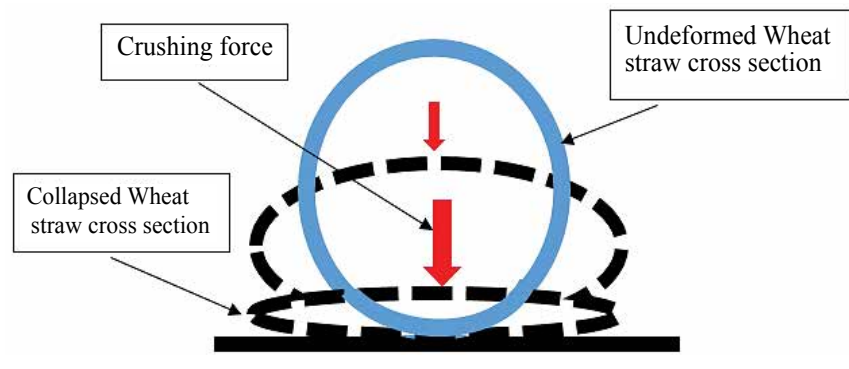

Figure 8: Crushing of the wheat straw composite.

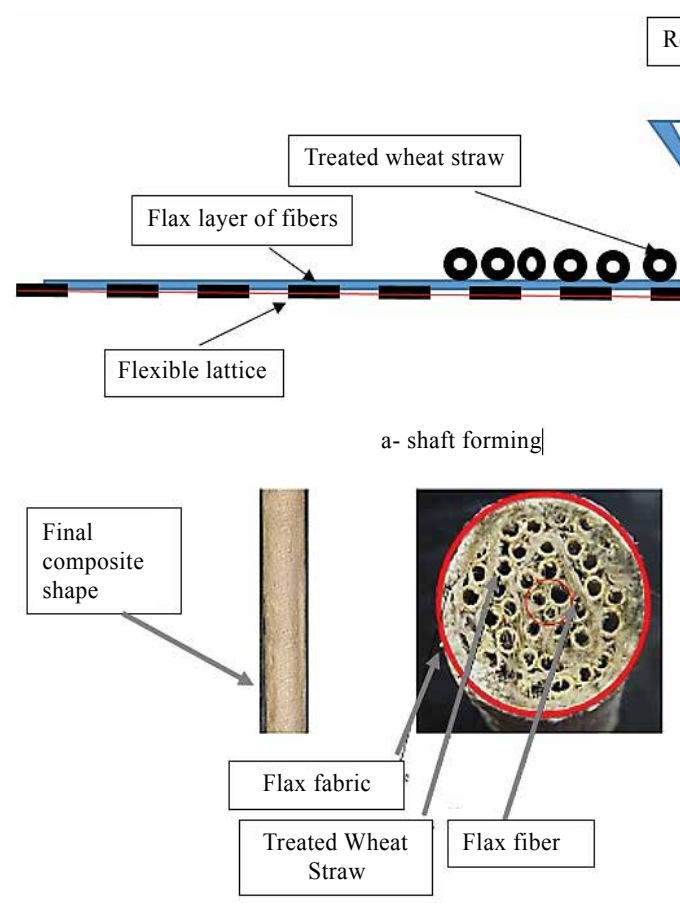

b- Final form and cross-section of the shaft

Figure 9: Wheat straw/flax fiber/flax fabric reinforced resin composite.

indicates that bending stress in the wall is continuously increasing as increases of hollowness while the contact pressure decreases. The deformation parabolically increases after hollowness value over $30 \%$, creating more stresses in the wall which leads to crack of the straw wall and crushing of its cross section. Due to thin wall section very less material is available to resist the force, so von Mises stress increases rapidly after $60 \%$ hollowness [23]. Consequently, the maximum crushing force decreases as a function of hollowness.

From the above analysis, one of the drawbacks of the Wheat straw is the low value of crushing force and bending stiffness. Consequently, the infusion of glue will help to increase crushing force. In order to determine the effect of the gelatin glue injection, crushing test was carried out to measure crushing force acting in the middle distance between the straw nodes. Specific crushing force is given in the Equation (2):

$$
\mathrm{F}_{\mathrm{s}}=\mathrm{F} / \mathrm{L}
$$

Where: $\mathrm{F}_{\mathrm{s}}$ - specific crushing force, $\mathrm{N} \cdot \mathrm{m}^{-1} ; \mathrm{F}$ - crushing force, $\mathrm{N}$; $\mathrm{L}$ - length of straw under pressing jaw, $\mathrm{mm}$.

The wheat straw started to crack under applied load at as low as $16 \mathrm{~N}$. When Wheat straw was covered with glue on the outer surface crushing force was increased up $40 \mathrm{~N}$ for untreated straw, while for the treated with infusion by the gelatin glue the cross section was deformed with no cracks in the straw surface. Moreover, the straw wall becomes more flexible; its cross-section is flattened under the applied load, as shown in Figure 8, with a noticeable increase of the crushing force reached $125 \mathrm{~N}$. Hence, the increase of the strength in the thin wall of the Wheat straw reflected directly on the crushing force under which the straw will crack.

The specific crushing force was $4.444 \mathrm{kN} / \mathrm{m}$ for composite straw against $0.421 \mathrm{kN} / \mathrm{m}$ for raw straw. This increase of specific crushing force is one of the most important advantages of the straw/glue composite, rendering its use possible in various applications.

\section{Application of wheat straw composite}

Suitable use of the Wheat straw composite is flat board or a round cross-section shaft. Round shaft hybrid composite was designed using Wheat straw/flax fibers and covered by a layer of flax fabric. The construction of shaft is made of several layers of Wheat straw; first layer (core) consists of three straws winded around by a bundle of flax fibers. Figure 9a illustrates the forming process. The rotation of the laid layer of flax fibers and the stacks around the core structure continues till the final diameter is reached. Flax fabric was wrapped on the formed structure as the outside layer. During the whole process, the resin (PVA) is continuously fed at the rate to insure the required fiber volume fraction of the final composite. In our case, the weight fraction for the straw, flax fibers, and fabric was $51 \%$ and composite density was $0.1125 \mathrm{~g} / \mathrm{cm}^{3}$. The shaft formation and cross section are shown in Figures $9 \mathrm{a}$ and $9 \mathrm{~b}$ respectively.

\section{Conclusion}

The potential use of treated Wheat straw/flax fiber as reinforcement in PVA was investigated. The study focused on whole stems of Wheat straw which were reinforced with injection of the animal glue to improve the strength and crushing force of the Wheat straw. Wheat straw tenacity increased by about $165 \%$, breaking strain by $125 \%$, and the Young's Modulus of elasticity by $125 \%$. The specific crushing force reached $4.444 \mathrm{kN} / \mathrm{m}$ for injected Wheat straw, while it was $0.421 \mathrm{kN} / \mathrm{m}$ for raw straw. The above supports the possibilities of consuming the whole wheat straw in a composite as an engineering material. Wheat straw stem infused by glue can be used to get low density composites with acceptable mechanical performance. Given method is applicable 
Citation: El Messiry M, El Deeb R (2016) Analysis of the Wheat Straw/Flax Fiber Reinforced Polymer Hybrid Composites. J Appl Mech Eng 5: 240. doi: $10.4172 / 2168-9873.1000240$

for fabrication of Wheat straw/flax fiber/flax fabric polymer composite in rod form.

\section{References}

1. El Messiry M (2016) Natural fiber textile composite engineering. Apple Academic Press Inc.

2. Mads A, Kristensen J, Felby C, Jorgensen H (2011) Pretreatment and enzymatic hydrolysis of wheat straw (Triticum aestivum L) The impact of lignin relocation and plant tissues on enzymatic accessibility Technology Volume February :1-12.

3. Avella M, La Rota G, Martuscelli E, Raimo M, Sadocco P et al. (2016) Poly (3-hydroxybutyrate-co-3-hydroxyvalerate) and wheat straw fiber composites: thermal mechanical properties and biodegradation behavior. J Composite Materials 35: 829-836.

4. Mantanis G, Nakos P, Berns J, Rigal L. (2008) Turning agricultural straw residues into value added composite products: A new environmentally friendly technology bio-composites from agricultural raw materials.

5. Hui Y, Ruigang L, Dawa S, Zhonghua W, Yong H (2008) Arrangement of cellulose microfibrils in the Wheat straw cell wall. Carbohydrate Polymers 72 $122-127$

6. Pearson C (2003) Animal glues and adhesives engineer material Handbook of 5. Adhesive Technology by Taylor \& Francis Group LLC.

7. Shanmugasundaram L (2009) Green composites: Manufacturing techniques \& applications the Indian textile journal.

8. Albano C, Karam A, Dominguez N, Sanchez Y, Gonzalez J (2005) Therma mechanical, morphological thermogravimetric, rheological and toxicological behavior of HDPE/Seaweed residues composites. J Composite Structures 71 282-288.

9. Yang HS, Kim HG, Son J, Lee BJ, Twang TS (2006) Rice husk flour filled with polypropylene composites, mechanical and morphological studies. J Composite Structure 63: 305-312.

10. Alvarez A, Kenny I, Vazquez A (2005) Influence of twin-screw processing conditions on the mechanical properties of biocomposites. J Composite Materials 39: 2023-2038.

11. Yasina M, Bhuttob A, Karimb A (2010) Efficient utilization of rice-wheat straw to produce value added composite products. Int J Chemical and Environmental Engineering 1: 136-148.

12. Grigoriou $\mathrm{AH}$ (2000) Straw-wood composites bonded with various adhesive systems. Wood Sci Technol: 34:355-365.
13. Han G, Zhang C, Zhang D, Umenura D, Kawai S (1998) Upgrading of urea formaldehyde bonded reed and Wheat straw particleboards using silane coupling agents. J Wood Sci 44: 282-286.

14. Wang D, Sun XS (2002) Low density particleboard from Wheat straw and corn pith. Ind Crops Prod 15: 43-50.

15. David AP (1997) Wood process adapted to straw particleboard. Wood Techno 124:20-24.

16. Karr GS, Sun XS (2013) Straw board from vapour phase acetylation of Wheat straw. Ind Crops Prod 11: 31-41.

17. Abba HA, Nur H, Salit S (2013) Review of agro waste plastic composites production. J Minerals and Materials Characterization and Engineering 1: 1-9.

18. Suhara-Panthapulakkal S, Sain M (2007) Agro-residue reinforced high-density polyethylene composites: Fiber characterization and analysis of composite properties. Composites: Part A 38:1445-1454.

19. Amirpouyan Sardashti A (2009) Wheat straw-clay-polypropylene hybrid composites. Waterloo Ontario Canada.

20. Fowler PA, Hughes JM, Elias RM (2006) Biocomposites: Technology environmental credentials and market forces. $J$ the Science of Food and Agriculture 86: 1781-1789.

21. Chevillard A, Angellier-Coussy H, Cuq B, Guillard V, Césa G, et al. (2011) How the biodegradability of Wheat gluten-based agromaterial can be modulated by adding nanoclays. Polymer Degradation and Stability.

22. Lam PS, Sokhansanj S, Bi X, Lim CJ, Naimi LJ et al. (2008) Bulk density of wet and dry wheat straw and switchgrass particles. Applied Engineering in Agriculture 24: 351-358.

23. Darji PH, Vakharia DP (2012) Development of graphical solution to determine optimum hollowness of hollow cylindrical roller bearing using elastic finite element analysis Finite Element Analysis Applications in Mechanical Engineering.

24. Schellmann N (2007) Animal glues: a review of their key properties relevant to conservation. Reviews in conservation 8: 55-66.

25. Von Endt D, Mary T (2007) The chemistry of filled animal glue systems.

26. Landrock A (1987) Adhesives technology. Handbook J Eng Mater Technol 109: 98.

27. Pizzi A, Mittal L, (2009) Handbook of adhesive technology (2ndedn). Hopewell Junction, New York USA. 